\title{
Effect of four serum components on survival of Treponema pallidum and its attachment to rabbit cells in vitro
}

\author{
G H W WONG, B STEINER, AND S GRAVES \\ From the Department of Microbiology, Monash University, Clayton, Victoria, Australia
}

SUMMARY Transferrin and, to a lesser extent, insulin were two components of serum that enhanced the survival of Treponema pallidum in microaerophilic, acellular medium. These two components also enhanced the attachment of $T$ pallidum to baby rabbit genital organ (BRGO) cells in both aerobic and microaerophilic tissue culture systems. Growth hormone and epidermal growth factor marginally enhanced the attachment of $T$ pallidum to BRGO cells.

\section{Introduction}

Treponema pallidum rapidly attaches to mammalian cells in tissue culture, and this appears to be related to $T$ pallidum pathogenesis. ${ }^{1-3}$ Blockage of attachment by immune serum correlates with resistance to superinfection in syphilis. ${ }^{4}$ Modulation of host cell metabolism by changes in the concentration of serum during in vitro cultivation, or by the use of metabolic inhibitors, affects the relation between the parasite, $T$ pallidum, and the host baby rabbit genital organ (BRGO) cells in vitro. 5 In the report published here we examine the effect of four individual components of serum (transferrin, insulin, growth hormone, and epidermal growth factor) on the survival of $T$ pallidum in vitro and on its attachment to BRGO cells.

\section{Materials and methods}

\section{SOURCE OF T PALLIDUM}

We propagated $T$ pallidum (Nichols strain) in adult male rabbits as described previously. 6 After the infected testes had been removed, they were sliced into pieces and extracted for $15-30$ minutes in a $150 \mathrm{ml}$ bottle containing 30-50 ml of medium under anaerobic conditions. ${ }^{7}$ The medium consisted of Eagle's minimum essential medium supplemented with $20 \%$ fetal calf serum, $10 \mathrm{mmol} / 1 \mathrm{~N}-2$-hydroxyethylpiperazine-N1-2-ethanesulphonic acid (HEPES), and $0.5 \mathrm{mmol} / \mathrm{l}$ dithiothreitol. We then separated extracted treponemes from rabbit tissue cells by

Address for reprints: Dr S Graves, Department of Microbiology, La Trobe University, Bundoora, Victoria, Australia 3083

Accepted for publication 9 May 1985 centrifuging the mixture at $1000 \times g$ for 10 minutes. We measured the concentration of $T$ pallidum by dark field microscopy using a bacterial counting chamber.

MEASURING MOTILITY RETENTION BY T PALLIDUM We extracted $T$ pallidum in serum free medium and added serum components as above. Incubation was microaerophilic at $34^{\circ} \mathrm{C}$ for 72 hours. $T$ pallidum concentration was $7 \times 106 / \mathrm{ml}$.

We examined 100 to $200 \mathrm{~T}$ pallidum from triplicate tubes at random by dark field microscopy, and recorded whether they were motile or non-motile.

\section{TISSUE CULTURE CELLS}

We used BRGO cells for all experiments. After their initial isolation the BRGO cells were maintained in Eagle's minimum essential medium with $10 \%$ fetal calf serum and $10 \mathrm{mmol} / 1 \mathrm{HEPES}$ without antibiotics at $37^{\circ} \mathrm{C}$. We changed medium every three days and subcultured monolayers once they reached confluency after 14-21 days. We removed the monolayer by washing with phosphate buffered saline (PBS) and then with PBS containing $0.025 \%$ trypsin and $0.001 \%$ ethylenediaminetetra-acetic acid (EDTA). We resuspended the cells in maintenance media, which we replated in Falcon tissue culture flasks or milk dilution bottles for routine passage.

COINCUBATION OF T PALLIDUM AND BRGO CELLS We seeded 1 to $5 \times 10^{4}$ BRGO cells into each Leighton tube containing a coverslip $(8 \times 32 \mathrm{~mm})$ one to two days before starting the experiment. We then washed the cells with PBS and placed them in serum free medium containing insulin (Commonwealth Serum Laboratories, Parkville, Australia) $50 \mathrm{~g} / 1$, growth 
hormone (Sigma, St Louis, USA) $50 \mathrm{mg} / \mathrm{l}$, epidermal growth factor (Collaborative Research, Waltham, Massachusetts, USA), $100 \mathrm{mg} / \mathrm{l}$, transferrin (Sigma) $50 \mathrm{mg} / \mathrm{l}$, or a combination of all four factors. For comparison, we exposed BRGO cells to the same Eagle's minimum essential medium containing $10 \%$ fetal calf serum. We added T pallidum $4 \times 107 / \mathrm{ml}$ and incubated the cultures either aerobically for four hours or microaerophilically for $\mathbf{2 4}$ hours, after which time we assess their attachment.

\section{MEASURING ATTACHMENT OF T PALLIDUM TO BRGO CELLS}

We removed cover slips from the Leighton tubes, washed off unattached treponemes with medium, and counted the number of treponemes attached to each BRGO cell under dark field microscopy. We recorded those attached to 30 to $40 \mathrm{BRGO}$ cells in duplicate or triplicate samples.

INCORPORATION OF TRITIATED URIDINE BY $T$ PALLIDUM

We used tritiated uridine ( $3 \mathrm{H}$-uridine) $1 \mathrm{MBq} / \mathrm{ml}$ $\left(20 \mu \mathrm{Ci} / \mathrm{ml}\right.$ per $2 \times 10^{7} T$ pallidum to measure ribonucleic acid (RNA) synthesis by $T$ pallidum under cell free microaerophilic conditions. We extracted $T$ pallidum micro-organisms in serum free medium, adjusted the concentration to $2 \times 107 / \mathrm{ml}$, and allowed them to incorporate ${ }^{3} \mathrm{H}$-uridine for 24 hours in the presence or absence of the four individual serum factors, all four factors combined, or $10 \%$ fetal calf serum. At the end of the labelling period we discarded the supernatant and solubilised the $T$ pallidum with $150 \mu \mathrm{l}$ of a mixture of $0.5 \mathrm{~mol} / \mathrm{l}$ sodium hydroxide and $0.5 \%$ sodium dodecyl sulphate. Using a multiple cell culture harvester (Skatron, Norway), we washed the treponemes sequentially with trichloroacetic acid $(5 \%)$, water, and methanol. We collected the precipitates on to glass fibre filters (Flow Laboratories), and measured radioactivity with a Packard Tricarb scintillation counter using $5 \mathrm{~g} / 1$ of 2,5-diphenyloxazole (PPO) and $0.4 \mathrm{~g} / 1$ of 1,4-bis [2-(3-methyl-5-phenyl-oxazolyl)]-benzene (dimethyl POPOP) in toluene as the scintillation fluid.

\section{Results}

\section{RETENTION OF T PALLIDUM MOTILITY}

Figure 1 shows that transferrin alone was as effective at retaining $T$ pallidum motility as $10 \%$ fetal calf serum or all four serum factors combined. Insulin was less effective, and growth hormone and epidermal growth factor even less so. Boiling the combined growth factors for $\mathbf{3 0}$ minutes destroyed this ability.

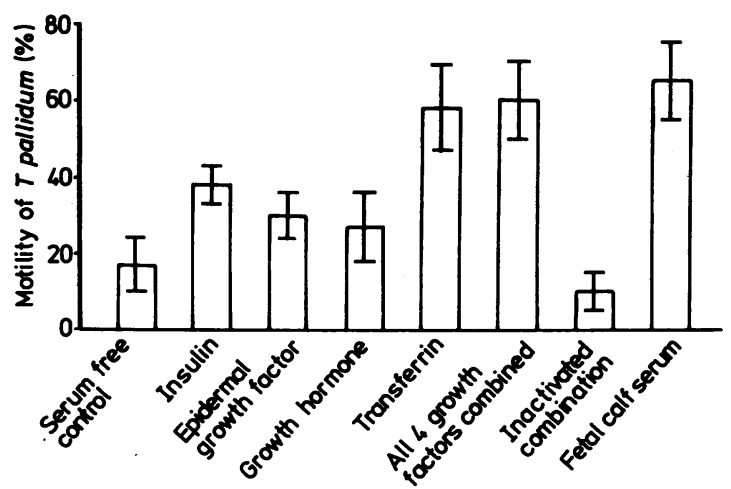

FIG 1 Retention of motility of Treponema pallidum in serum free medium containing insulin, epidermal growth factor, growth hormone, transferrin, all four growth factors combined, combination of all four factors inactivated by boiling for 30 minutes, or $10 \%$ fetal calf serum after microaerophilic incubation for 72 hours at $34^{\circ} \mathrm{C}$ in cell free medium. Each bar represents standard deviation of 30-40 assessments.

TABLE Ribonucleic acid synthesis by Treponema pallidum as measured by uptake of tritiated uridine over 24 hours in the presence of four serum factors, individually or combined, or $10 \%$ fetal calf serum. Numbers are mean (SD) of 10 samples

\begin{tabular}{lc}
\hline Serum factor & $\begin{array}{c}\text { Uptake of }{ }^{3} \text { H-uridine } \\
\text { (counts per min/well) }\end{array}$ \\
\hline No serum or serum factor & $63(26)$ \\
$10 \%$ Fetal calf serum & $143(30)$ \\
Insulin & $135(27)$ \\
Transferrin & $113(41)$ \\
Epidermal growth factor & $94(15)$ \\
Growth hormone & $69(30)$ \\
All four serum factors combined & $165(32)$ \\
All four serum factors combined & $50(11)$ \\
and inactivated &
\end{tabular}

INCORPORATION OF ${ }^{3}$ H-URIDINE BY $T$ PALLIDUM

The table shows that insulin and all four serum factors combined permitted RNA synthesis equivalent to that obtained with $10 \%$ fetal calf serum. Transferrin, growth hormone, epidermal growth factor, and inactivated combined serum factors were less effective than $10 \%$ fetal calf serum.

ATTACHMENT OF T PALLIDUM TO BRGO CELLS

Figure 2 shows that all four serum factors enhanced $T$ pallidum attachment, transferrin and insulin being superior to growth hormone and epidermal growth factor. The combination of all four factors combined was appreciably better than any individual factor, yet $10 \%$ fetal calf serum was the best. This was true in 


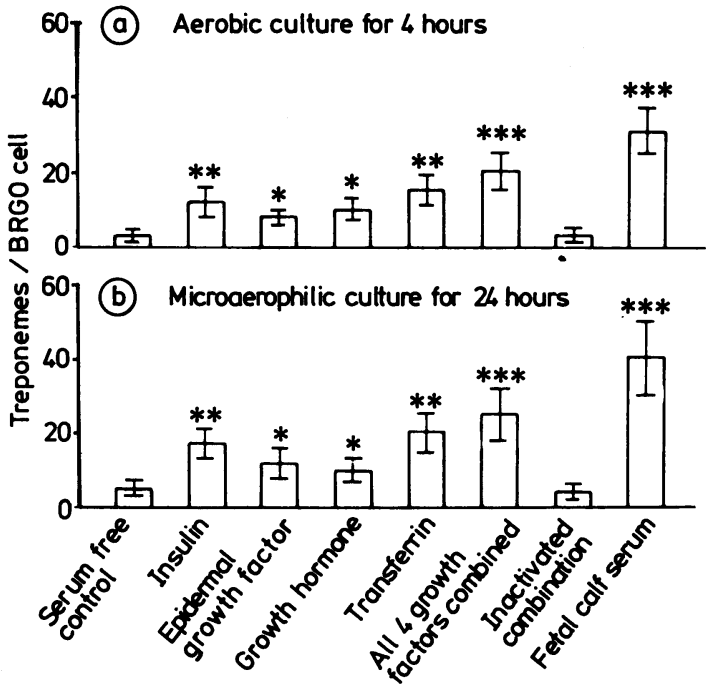

FIG 2 Attachment of Treponema pallidum $\left(4 \times 10^{7} / \mathrm{ml}\right)$ to baby rabbit genital organ $(B R G O)$ cells $\left(1 \times 10^{4} / \mathrm{ml}\right)$ in serum free medium containing insulin, epidermal growth factor, growth hormone, transferrin, all four growth factors combined, combination of all four factors inactivated by boiling for 30 minutes, or $10 \%$ fetal calf serum by (a) aerobic culture for four hours and (b) microaerophilic culture for 24 hours. Each bar represents standard deviation of 30-40 assessments. Differences between results and those for serum free control: ${ }^{*} p<0.05,{ }^{* *} p<0.01,{ }^{* * *} p<0.001$.

both aerobic and microaerophilic conditions. When combined growth factors were inactivated by boiling for $\mathbf{3 0}$ minutes, the stimulatory activity was destroyed and the number of attached treponemes was similar to that found for the serum free control. The complex serum requirements of mammalian cells are probably also necessary for the optimum attachment of $T$ pallidum to these cells.

\section{Discussion}

We have shown previously that metabolically active tissue cells provide a more suitable habitat for $T$ pallidum attachment than do resting cells. ${ }^{5}$ At present it is not known what growing cells provide that alters $T$ pallidum attachment, but both surface receptors 8 and extracellular surface glycoproteins, such as fibronectin, ${ }^{9}$ are altered depending on the growth state of the cell. Extracellular matrix components may affect attachment of $T$ pallidum to host cells. 10 Fibronectin has been implicated as a potential ligand for $T$ pallidum attachment to host cells. ${ }^{9}$ Thus alterations in host cell surface properties may be related to $T$ pallidum attachment.

As the metabolic state of the host cell appears to be important in extracellular parasitism by $T$ pallidum, four growth modulatory serum components were tested for their effect on the relation between host and parasite. The most dramatic effect was shown by the iron transport protein, transferrin. Transferrin was as effective as $10 \%$ serum in maintaining $T$ pallidum motility, and it appreciably increased the degree of attachment to BRGO cells. The reason for the transferrin effect is not known, but may concern its binding of iron. It could either act by donating necessary iron to $T$ pallidum or perhaps by chelating iron and removing it from the free state, thus preventing it entering the $T$ pallidum cell. This latter effect could be important because $T$ pallidum is very sensitive to oxygen reduction products, 11 and the hydroxyl radical can be formed intracellularly in iron loaded bacteria.12 It may also have a direct effect on the BRGO cells, and this effect may secondarily enhance $T$ pallidum attachment and viability.

We thank Mrs L Drummond for her excellent technical help. The work was supported by an Australian National Health and Medical Research Council grant to SG.

\section{References}

1. Fitzgerald TJ, Johnson RC, Miller JN, Sykes JA. Characterization of the attachment of Treponema pallidum (Nichols strain) to cultured mammalian cells and the potential relationship of attachment to pathogenicity. Infect Immun 1977;18:467-78.

2. Hayes NS, Muse KE, Collier AM, Baseman JB. Parasitism by virulent Treponema pallidum of host cell surfaces. Infect Immun 1977;17:174-86.

3. Wong GHW, Steiner B, Faine S, Graves S. Factors affecting the attachment of Treponema pallidum to mammalian cells in vitro. British Journal of Venereal Diseases 1983;59:21-9.

4. Wong GHW, Steiner B, Graves S. Effect of syphilitic rabbit sera taken at different periods after infection on the treponemal motility, treponemal attachment to cultured mammalian cells in vitro, and treponemal infection in rabbits. British Journal of Venereal Diseases 1983;59:220-4.

5. Wong GHW, Steiner B, Faine S, Graves $S$. Effect of serum shift up and metabolic inhibitors on the attachment of Treponema pallidum to cultured rabbit cells. J Med Microbiol 1983;16:281-93.

6. Steiner B, McLean I, Graves S. Redox potential and survival of virulent Treponema pallidum under microaerophilic conditions. British Journal of Venereal Diseases 1981;57:295-301.

7. Wong GHW, Steiner BM, Graves SR. Effects of anaerobic and microaerophilic conditions of extraction and incubation on the survival of Treponema pallidum in vitro. British Journal of Venereal Diseases. 1982;58:139-42.

8 Kruth HM, Avigan J, Gamble W, Vaugh W. Effect of cell density on binding and uptake of low density lipoprotein by human fibroblasts. J Cell Biol 1979;83:588-94.

9. Peterson KM, Baseman JB, Alderete JF. Treponema pallidum receptor binding proteins interact with fibronectin. $J$ Exp Med 1983;157:1958-70.

10. Fitzgerald TJ. Pathogenesis and immunology of Treponema pallidum. Annu Rev Microbiol 1981;35:29-54.

11. Steiner B, Wong GHW, Graves S. Susceptibility of Treponema pallidum to the toxic products of oxygen reduction and the nontreponemal nature of its catalase. British Journal of Venereal Diseases 1984;60:14-22.

12. Repine JE, Fox RB, Berger EM. Hydrogen peroxide kills Staphylococcus aureus by reacting with staphylococcal iron to form hydroxyl radical. J Biol Chem 1981;256:7094-6. 